\title{
DOPRINOS MORALNIH TEMELJA, RELIGIOZNOSTI I DRUŠTVENE IDEOLOGIJE U OBJAŠNJENJU ORIJENTACIJA PREMA SREĆI
}

\author{
Nikola Erceg \\ Odsjek za psihologiju, Filozofski fakultet, Sveučilište u Zagrebu \\ Ivana Lucića 3, 10000 Zagreb \\ nerceg@ffzg.hr \\ Andreja Bubić \\ Katedra za psihologiju, Filozofski fakultet, Sveučilište u Splitu \\ Poljička 35, 21000 Split \\ abubic@ffst.hr
}

\begin{abstract}
Sažetak
Istraživanje načina na koji pojedinci konceptualiziraju sreću, odnosno njihovih uvjerenja o tome što čini sretan život predstavlja važan element razumijevanja subjektivne dobrobiti jer ova uvjerenja ne reflektiraju samo njihova razmišljanja već i utječu na subjektivni osjećaj sreće. Istraživanja takvih uvjerenja pokazala su da postoje tri temeljne orijentacije koje naglašavaju mogućnost dostizanja sreće putem ugodnog, smislenog ili angažiranog života. S obzirom na to da nije dovoljno poznato koji činitelji doprinose razvoju spomenutih orijentacija, na uzorku od 415 sudionika provedeno je istraživanje čiji je cilj bio odrediti ulogu religioznosti, društvene ideologije i pet moralnih temelja koji uključuju brižnost, pravednost, lojalnost prema vlastitoj skupini, poštovanje autoriteta te tjelesnu i duhovnu čistoću u objašnjenju orijentacija prema sreći. Dobiveni rezultati izdvojili su moralne temelje lojalnosti i podložnosti autoritetu te liberalniju društvenu ideologiju i mlađu životnu dob kao statistički značajne prediktore orijentacije prema ugodnom životu. Uz to, moralni temelji brižnosti, lojalnosti i čistoće, kao i liberalnija društvena orijentacija, predviđali su izraženiju orijentiranost prema angažiranom životu, pri čemu se brižnost, zajedno s religioznošću, pokazala i kao značajan prediktor orijentacije prema smislenom životu. Dobiveni rezultati pokazuju da orijentacijama prema sreći, odnosno uvjerenjima pojedinaca o tome što predstavlja najbolji put prema sreći, doprinose njihova temeljna moralna, vjerska i društvena uvjerenja te upućuju na potrebu daljnjih istraživanja međuodnosa vrijednosnih orijentacija, zadovoljstva životom i orijentacija prema sreći.
\end{abstract}

Ključne riječi: društvena ideologija, moralni temelji, orijentacije prema sreći, religioznost, subjektivna dobrobit 


\section{UVOD}

Subjektivna dobrobit i sreća fenomeni su od važnosti i interesa ne samo istraživačima već i laicima u svakodnevnom životu. Razmišljajući o tome što znači biti sretan i što je potrebno za postizanje sreće, ljudi konstruiraju implicitne teorije o sreći, odnosno laička uvjerenja o tome kako biti sretan te često smatraju kako su, primjerice, socijalne veze, osjećaj unutarnjeg mira i harmonije, pozitivan afekt, autonomija, životna postignuća, sloboda ili nedostatak nesreće povezani sa srećom $\mathrm{i}$ životnim zadovoljstvom (Brdar i Anić, 2010; Delle Fave, Brdar, Freire, Vella-Brodrick i Wissing, 2016; Furhnam i Cheng, 2000; Lu i Gilmour, 2004; Pflug, 2009). Iako takva razmišljanja nisu nužno presudna za subjektivnu dobrobit jer na nju nezanemarivo utječu stabilne karakteristike ličnosti te genetski utjecaji (Fujita i Diener, 2005; Lyubomirsky, Sheldon, i Schkade, 2005), čini se kako određena ponašanja, razmišljanja i vjerovanja ipak doprinose razinama sreće pojedinca (Emmons i McCullough, 2003; Keltner i Bonanno, 1997; Lyubomirsky i sur., 2005; Sheldon i Houser-Marko, 2001). U skladu s tim, neka istraživanja su pokazala kako implicitne teorije o sreći mogu utjecati na ponašanja koja pojedinci biraju kako bi ostvarili vlastitu ili sreću drugih ljudi (Dweck, Chiu, i Hong, 1995; Furnham i Cheng, 2000). Dakle, iako laička uvjerenja o tome što ljude čini sretnima ne moraju nužno biti točna, ona su ipak značajna jer oblikuju razmišljanja i ponašanja koja pojedinac bira u svrhu postizanja sreće te na taj način utječu na stvarnu razinu dobrobiti i sreće koju postiže.

Usko povezan s implicitnim teorijama o sreći je i pojam orijentacija prema sreći koji su uveli Peterson, Park i Seligman (2005) kako bi klasificirali načine i strategije koje pojedinci koriste za postizanje sreće u životu. Navedeni autori izdvojili su tri različite vrste uvjerenja pojedinaca o načinima ostvarivanja sreće: ljudi se u potrazi za srećom mogu orijentirati prema ugodnom, smislenom i angažiranom životu. Pojedinci orijentirani prema ugodnom životu sreću traže kroz maksimiziranje ugodnih te minimiziranje neugodnih afekata i događaja. Za razliku od njih, oni orijentirani prema smislenom životu sreću vide u razvijanju vlastitih potencijala i njihovu korištenju u svrhu postizanja viših ciljeva i dobrobiti drugih ljudi. Pojedinci orijentirani prema angažiranom životu sreću pronalaze u aktivnostima koje ih zaokupljaju, na koje su u potpunosti fokusirani, uz koje izgube pojam o vremenu i koje ih dovedu u stanje tzv. flow- $a$, odnosno "očaravajuće obuzetosti" (Csikszentmihalyi, 2014). Pokazalo se kako su pojedinci s višim rezultatom na sve tri dimenzije, odnosno osobe koje teže "ispunjenom životu" značajno zadovoljnije životom od onih s niskim rezultatima na sve tri dimenzije istovremeno (Peterson i sur., 2005). Osim za zadovoljstvo životom, orijentacije su se pokazale relevantnima i za doživljavanje pozitivnog i negativnog afekta, kao i za različite karakterne snage povezane sa zadovoljstvom životom (Brdar i Kashdan, 2010; Peterson i sur., 2005; Peterson, Ruch, Beermann, Park, i Seligman, 2007; Vella-Brodrick, Park, i Peterson, 2009). Iako je važnost orijentacija prema sreći za subjektivnu dobrobit i zadovoljstvo životom potvrđena, istraživanja se do sada nisu sustavno bavila pitanjem činitelja koji utje- 
ču na njihovo formiranje. S obzirom na to, provedeno je istraživanje čiji je cilj bio identificirati neke od odrednica ovih orijentacija kako bi se doprinijelo razumijevanju njihove strukture i razvoja.

Iako zasada nije poznato kako i zašto različiti pojedinci razvijaju pojedine orijentacije prema sreći, na temelju prethodnih nalaza poznato je kako su njihova razmišljanja o sreći i njezinim uzrocima povezana s osobinama ličnosti (Pollock, Noser, Holden, i Zeigler-Hill, 2015), kao i nekim općenitim promišljanjima o životu te životnim i moralnim vrijednostima (Braaten i Huta, 2018; Bubić i Erceg, 2018; Furnham i Cheng, 2000; Lu i sur., 2001; Lu i Shih, 1997; Peterson i sur., 2007). Prema Haidtu i Kesebiru (2010), moralni sustav je isprepleteni set vrijednosti, vrlina, normi, praksi, identiteta, institucija, tehnologija i evoluiranih psiholoških mehanizama koji zajedno rade na suzbijanju i reguliranju sebičnosti te omogućavanju zajedničkog života. Iako su brojni raniji autori smatrali kako je moralna dimenzija ograničena prvenstveno na reguliranje odnosa među pojedincima, odnosno na procjene o tome je li netko bio pravedan ili brižan prema drugome (Gilligan, 1983; Kohlberg, 1969), Haidt i Kesebir (2010) navode kako su moralnom sudu podložna i ona ponašanja koja direktno ne podliježu procjeni samo na ovim dimenzijama. Primjerice, konsenzualna homoseksualna veza će kod nekih ljudi izazvati snažnu moralnu osudu iako se u tom kontekstu ne može govoriti o nedostatku brižnosti ili pravednosti. Kako bi objasnili ovakve fenomene, Haidt i Joseph (2004) razvili su tzv. teoriju moralnih temelja prema kojoj se pojedinci, ali i kulture, razlikuju po tome na koje elemente stavljaju naglasak pri donošenju moralnih prosudbi. Autori pritom razlikuju pet moralnih temelja: brižnost, pravednost, lojalnost prema vlastitoj skupini, poštovanje autoriteta te tjelesnu i duhovnu čistoću. Brižnost se odnosi na osjetljivost na okrutnosti i ugrožavanje drugih te, povezano s time, vrline ljubaznosti, dobrote i suosjećanja. Pravednost se očituje u zabrinutosti zbog nepravednog postupanja prema drugim ljudima i nejednakih ishoda, a s njom su povezane vrline poštenja i pravde. Lojalnost prema vlastitoj skupini očituje se u socijalnim emocijama povezanim s povjerenjem i suradnjom s pojedincima unutar vlastite grupe, kao i u opreznosti i nepovjerenju prema pripadnicima drugih grupa. Neke od vrlina povezanih s ovim temeljem su odanost, patriotizam i heroizam. Poštovanje autoriteta je povezano sa socijalnim odnosima i dužnostima u hijerarhijskim odnosima, a na toj osnovi nastaju vrline poput liderstva, dužnosti, poslušnosti $\mathrm{i}$ ispunjavanja vlastite uloge. Konačno, tjelesna i duhovna čistoća uglavnom se odnosi na brigu povezanu s duhovnom i tjelesnom "zaraženošću" te vrlinama poput čednosti i kontrole požude (Haidt i Graham, 2007; Haidt, Graham, i Joseph, 2009).

Prethodna istraživanja su pokazala kako su moralni temelji povezani i s drugim osobnim, primjerice religioznim te društvenim i političkim uvjerenjima pojedinaca. Među ovima, naročito se izdvajaju ideološke pozicije, odnosno društveni svjetonazor, pa tako osobe liberalnog svjetonazora postižu znatno više rezultate od konzervativaca na prva dva temelja brižnosti i pravednosti koji se najčešće zajedničkim imenom nazivaju "individualizirajućim" temeljima. Drugim riječima, za 
njih ponašanja koja nisu ograničena na odnos između pojedinaca te koja se ne mogu procijeniti na temeljima brižnosti i pravednosti nisu podložna moralnom sudu. S druge strane, konzervativci postižu više rezultate na tzv. "povezujućim temeljima" lojalnosti prema vlastitoj skupini, poštovanja autoriteta te tjelesne i duhovne čistoće, a moralni sustav podjednako im se oslanja na svih pet temelja (Graham, Haidt, i Nosek, 2009). Osim s ideološkim pozicijama, moralni su temelji povezani i s religioznim uvjerenjima, pa tako religiozniji pojedinci, slično kao oni konzervativni, uglavnom imaju više izražene tzv. "povezujuće" moralne temelje (Graham i Haidt, 2010 .

Osim na usku međuovisnost ovih varijabli, ranija istraživanja upućuju i na povezanost vrijednosti, ideoloških svjetonazora i religioznosti sa subjektivnom dobrobiti pojedinaca. Na primjer, u nešto širem kontekstu vrijednosnih orijentacija (Schwartz, 1992, 2003), pojedinci koji otvorenost za promjene i socijalnu podršku ističu kao osobne vrijednosti pokazuju i više razine trenutačne sreće (Bubić i Erceg, 2018). Nadalje, većina istraživanja pokazuje da je konzervativnost pozitivno povezana sa srećom i zadovoljstvom životom (Onraet, Van Hiel i Dhont, 2013; Taylor, Funk i Craighill, 2006), pri čemu još nema konsenzusa o tome što točno uzrokuje taj "ideološki jaz" u zadovoljstvu životom, razlike u kognitivnim stilovima i motivaciji ili osobinama ličnosti konzervativaca i liberala (Jost, Nosek, i Gosling, 2008; Napier i Jost, 2008; Schlenker, Chambers, i Le, 2012). Neovisno o tome, ovi rezultati upućuju na razlike u uvjerenjima konzervativaca i liberala o najboljim načinima postizanja sreće, na temelju čega se može postaviti hipoteza kako bi se te dvije skupine mogle razlikovati prema svojim orijentacijama prema sreći. Pritom se može pretpostaviti kako bi razlike među njima mogle biti ovisne i o njihovim drugim, a ne samo društveno-političkim uvjerenjima, odnosno religioznim i drugim vrijednostima ovih pojedinaca koja su također povezana sa subjektivnom dobrobiti. Naime, mnoštvo istraživanja upućuje na višu sreću religioznijih pojedinaca u odnosu na nereligiozne, čak i kad se kontrolira za varijable poput dobi, spola, rase, obrazovanja, dohotka i bračnog statusa (Graham i Haidt, 2010; Myers, 2000; Seybold i Hill, 2001), što se može povezati s činjenicom da vjera u boga ljudima pruža utjehu u trenucima u kojima nemaju osobnu kontrolu i socijalnom integracijom koja se veže uz pripadanje vjerskim zajednicama (Lim i Putnam, 2010; McCullough i Willoughby, 2009).

Ukupno gledajući, na temelju dosadašnjih istraživanja može se zaključiti kako su moralni temelji, religioznost i društvene ideologije pojedinaca povezani s njihovom subjektivnom dobrobiti, pri čemu je barem dio te povezanosti određen njihovim specifičnim uvjerenjima i promišljanjima. S obzirom na to, može se spekulirati kako moralne, religiozne i društvene vrijednosti pojedinaca doprinose subjektivnoj dobrobiti putem orijentacija prema sreći, što bi bilo u skladu s pretpostavkama o medijatornoj ulozi orijentacija prema sreći u objašnjenju veza između osobina ličnosti i subjektivne dobrobiti (Pollock i sur., 2015). U tom kontekstu, moguće je postaviti hipotezu prema kojoj moralni temelji, religioznost i društvene ideologije pojedinaca 
doprinose izraženosti njihovih orijentacija prema sreći, što je ispitano provedenim istraživanjem. Pritom smo očekivali kako će konzervativnost biti negativno povezana s orijentacijom prema ugodnom životu, što bi bilo u skladu s prethodnim istraživanjima koja su pokazala kako su konzervativci religiozniji (Graham i Haidt, 2010), savjesniji (Carney, Jost, Gosling, i Potter, 2008) i manje otvoreni prema novim iskustvima (Carney i sur., 2008; Verhulst, Eaves, i Hatemi, 2012) od liberala, od kojih također postižu više rezultate na mjeri protestantske radne etike i vrijednosti samokontrole (Feather, 1984). Također, s obzirom da konzervativce karakterizira visok rezultat na moralnim temeljima lojalnosti prema vlastitoj skupini, poštovanju autoriteta te duhovnoj i tjelesnoj čistoći (Graham i Haidt, 2010), očekivali smo da će navedeni moralni temelji biti negativno povezani s orijentacijom prema ugodnom životu. Nadalje, s obzirom da postoje naznake o povezanosti religioznosti s većom samokontrolom i samoregulacijom (McCullough i Willoughby, 2009), odgađanjem zadovoljstva (Harrison i McKay, 2013) te smanjenom impulzivnošću (Baumeister, Bauer, i Lloyd, 2010), pretpostavili smo da će religioznost biti negativno povezana s orijentacijom prema ugodnom životu. Uz to, s obzirom da duhovna vjerovanja i religioznost pružaju osjećaj svrhe, životni smisao i usmjerenje, odnosno da pomažu naći smisao kod različitih životnih situacija i događaja te pružaju utjehu u teškim trenucima (Schlenker i sur., 2012), pretpostavili smo da će religioznost biti pozitivno povezana s orijentacijom prema smislenom životu.

\section{METODOLOGIJA}

\section{Sudionici istraživanja}

U istraživanju je sudjelovalo 415, od kojih 147 muških (35,4 \%) i 268 (64,6 $\%$ ) ženskih sudionika (prosječna starost 26,1 godine, $S D=10,74)$. Sudionici su regrutirani uz pomoć studenata Sveučilišta u Splitu u okviru kolegija o donošenju odluka. Sudjelovanje u istraživanju bilo je dobrovoljno i anonimno, u skladu s etičkim standardima institucije. Sudionicima je na početku kratko objašnjen postupak i svrha istraživanja, nakon čega su zamoljeni za suradnju i iskrenost u odgovaranju. Svi sudionici koji su zamoljeni za sudjelovanje pristupili su istraživanju koje je trajalo oko 15 minuta.

\section{Mjerni instrumenti}

U sklopu ovog istraživanja, sudionici su davali svoje procjene na sljedećim instrumentima: Skala orijentacija prema sreći (Peterson i sur., 2005), Upitnik moralnih temelja (Graham i sur., 2009) te Kratka ljestvica religioznosti (Bezinović, Marinović Bobinac, i Marinović Jerolimov, 2005). Uz to, sudionici su procijenili 
svoju društvenu ideologiju uz pomoć čestice "U društvenim pitanjima, rekao bih da je moja pozicija izrazito" (1 - liberalna, 5 - konzervativna), što je u skladu s prethodnim istraživanjima koja su društvenu ideologiju procjenjivala na usporediv način (Carney i sur., 2008). Pritom je prosječna procjena sudionika na ovoj čestici bila $M=2,84(S D=1,12)$

Skala orijentacija prema sreći (Peterson i sur., 2005) sastoji se od tri subskale, od kojih svaka mjeri jednu od orijentacija prema sreći, a sudionici svoje procjene daju na skali od sedam stupnjeva ( 1 - uopće se ne slažem; 7 - u potpunosti se slažem). Po šest čestica mjeri orijentaciju prema ugodnom životu (npr. Život je prekratak da bismo odgađali zadovoljstva koja nam može pružiti), orijentaciju prema smislenom životu (npr. Moj život ima trajni smisao), te orijentaciju prema angažiranom životu (npr. Što god da radim, vrijeme mi brzo prolazi).

Upitnik moralnih temelja (Graham i sur., 2009) sastoji se od ukupno 20 čestica, dakle, svaki od pet moralnih temelja (brižnost, pravednost, poslušnost autoritetu, lojalnost prema vlastitoj skupini, tjelesna i duhovna čistoća) zahvaćen je s ukupno četiri čestice podijeljene na dva dijela upitnika. Naime, prvi dio instrumenta od sudionika traži da na skali od šest stupnjeva (1 - uopće nije važno; 6 - izrazito je važno) procijeni koliko je neko djelo relevantno za davanje moralne prosudbe (npr. Je li netko skrbio za slabe i nemoćne ili nije ili Je li netko prekršio pravila čednosti i pristojnosti ili nije), dok je u drugom dijelu upitnika zadatak sudionika procijeniti stupanj slaganja (1 - uopće se ne slažem; 6 - u potpunosti se slažem) s navedenim tvrdnjama (npr. Pravda je najvažniji preduvjet nekog društva ili Muškarci $i$ žene imaju različite uloge u društvu).

Kratka ljestvica religioznosti (Bezinović i sur., 2005) sastoji se od pet tvrdnji, a sudionici na skali od pet stupnjeva ( 1 - uopće se ne slažem; 5 - u potpunosti se slažem) procjenjuju slaganje s tim tvrdnjama (npr. Imam osjećaj da me Bog čuva).

Deskriptivni podaci korištenih instrumenata prikazani su u Tablici 1.

Tablica 1. Deskriptivni podaci mjernih instrumenata korištenih u istraživanju

\begin{tabular}{lccccc}
\hline Instrumenti & $M$ & $S D$ & Min & Max & Cronbach $\alpha$ \\
\hline Brižnost & 18,93 & 3,37 & 6,00 & 24,00 & 0,60 \\
Pravednost & 20,80 & 2,66 & 9,00 & 24,00 & 0,61 \\
Lojalnost & 17,50 & 3,61 & 4,00 & 24,00 & 0,60 \\
Autoritet & 18,09 & 3,73 & 5,00 & 24,00 & 0,66 \\
Čistoća & 17,52 & 3,81 & 5,00 & 24,00 & 0,63 \\
Religioznost & 19,14 & 5,51 & 5,00 & 25,00 & 0,89 \\
Orijentacija prema ugodnom životu & 30,37 & 6,44 & 6,00 & 42,00 & 0,77 \\
Orijentacija prema smislenom životu & 28,30 & 6,86 & 6,00 & 42,00 & 0,80 \\
Orijentacija prema angažiranom životu & 26,57 & 5,98 & 9,00 & 65,00 & 0,70 \\
\hline
\end{tabular}




\section{REZULTATI}

Nakon što su formirani ukupni rezultati na korištenim mjernim instrumentima, provedena je korelacijska analiza s ciljem utvrđivanja povezanosti između orijentacija prema sreći i ostalih varijabli korištenih u ovom istraživanju. Rezultati korelacijske analize pokazali su da su sudionici koji su postigli viši rezultat na subskali orijentacije prema ugodnom životu također u prosjeku imali više rezultate na svim subskalama moralnih temelja osim na subskali čistoće, ali niže na čestici koja mjeri društvenu ideologiju. Drugim riječima, sudionici s višim rezultatom na orijentaciji prema ugodnom životu češće su bili liberalnijih svjetonazora, dok religioznost nije bila povezana s ovom orijentacijom prema sreći. Orijentacija prema smislenom životu bila je pozitivno povezana s religioznošću, kao i s rezultatima na svim moralnim temeljima, dok povezanost između te orijentacije i ideologije nije bila značajna. Orijentacija prema angažiranom životu bila je pozitivno povezana sa svim moralnim temeljima, ali ne i s religioznošću i društvenom ideologijom. Sveukupno, najveće korelacije s ostalim varijablama pokazala je orijentiranost na smisleni život, dok su varijable korištene $u$ istraživanju u prosjeku najmanje korelirale s orijentacijom prema ugodnom životu.

Korelacije između svih varijabli u ovom istraživanju prikazane su u Tablici 2.

Kako bi se identificirao doprinos pojedinih varijabli u objašnjenju pojedinačnih orijentacija prema sreći, provedene su tri hijerarhijske regresijske analize $u$ kojima su kao kriteriji uzete tri orijentacije prema sreći, dok su kao prediktori u prvom koraku uvrštene kontrolne varijable spola i dobi, u drugom pet moralnih temelja, a u trećem religioznost i ideologija. Sva tri regresijska modela objašnjavala su značajan dio varijanci orijentacija prema sreći, s tim da su korišteni prediktori objasnili najveći dio varijance orijentacije prema smislenom životu $(24,0 \%)$ te nešto manji dio varijanci orijentacija prema ugodnom $(17,4 \%)$ i angažiranom životu (13,3\%). Vezano uz pojedinačne prediktore, viši rezultati na moralnim temeljima lojalnosti i podložnosti autoritetu, kao i liberalnija društvena ideologija te mlađa životna dob značajno su predviđali izraženiju orijentaciju prema ugodnom životu. S druge strane, viši rezultati na moralnom temelju brižnosti i religioznosti značajno su predviđali višu orijentaciju prema smislenom životu, dok su viši rezultati na temeljima brižnosti, lojalnosti i čistoće, kao i liberalnija društvena orijentacija, predviđali izraženiju orijentiranost prema angažiranom životu.

Rezultati provedenih hijerarhijskih regresijskih analiza prikazani su u Tablici 3 . 


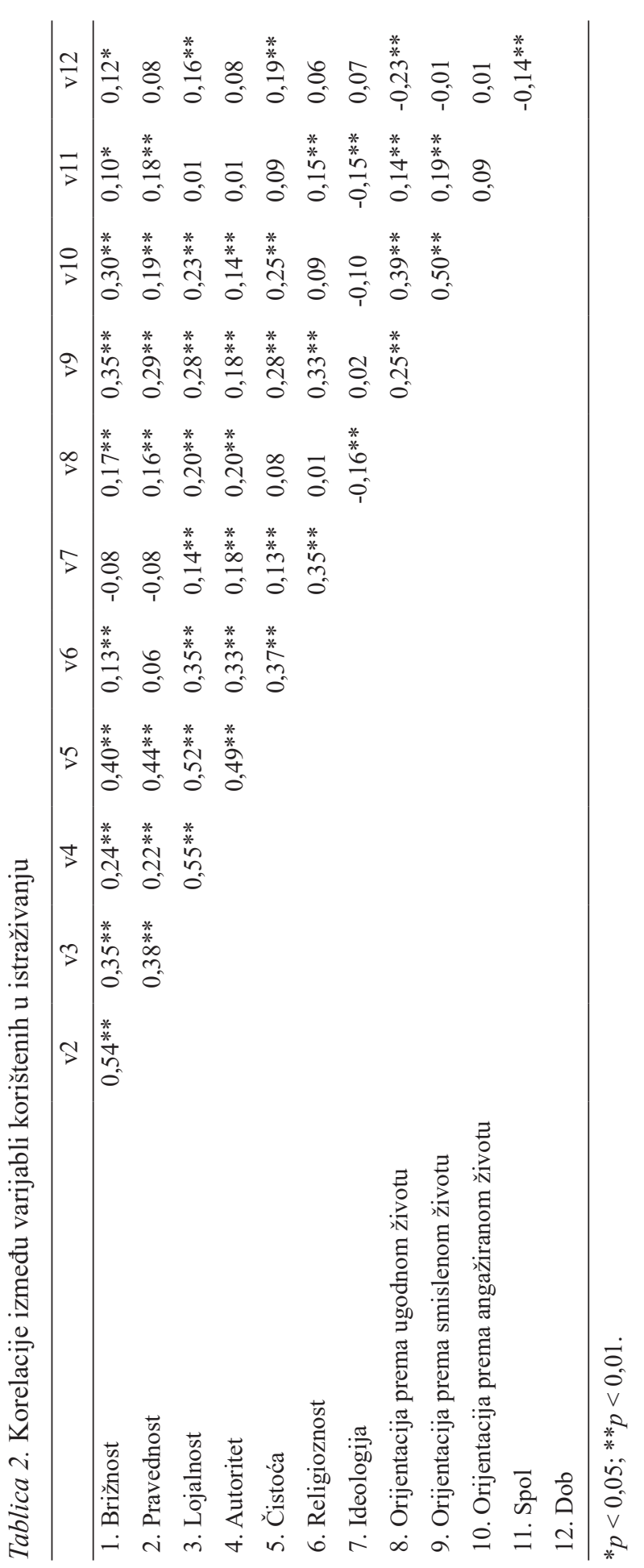


Tablica 3. Rezultati hijerarhijskih regresijskih analiza s kontrolnim varijablama spola i dobi te moralnim temeljima, ideologijom i religioznošću kao prediktorima i orijentacijama prema sreći kao kriterijima

\begin{tabular}{|c|c|c|c|}
\hline \multirow[b]{2}{*}{$\begin{array}{l}\text { Prediktori } \\
\qquad(\beta)\end{array}$} & \multicolumn{3}{|c|}{ Kriteriji } \\
\hline & $\begin{array}{l}\text { Orijentacija prema } \\
\text { ugodnom životu }\end{array}$ & $\begin{array}{l}\text { Orijentacija prema } \\
\text { smislenom životu }\end{array}$ & $\begin{array}{l}\text { Orijentacija prema } \\
\text { angažiranom životu }\end{array}$ \\
\hline Spol & $0,12 *$ & $0,19 * *$ & 0,10 \\
\hline Dob & $-0,21 * *$ & 0,02 & 0,03 \\
\hline $\mathrm{R}$ & 0,25 & 0,19 & 0,10 \\
\hline $\mathrm{R}^{2}$ & 0,06 & 0,04 & 0,01 \\
\hline$F(2,411)$ & $13,79 * *$ & $7,42 * *$ & 1,98 \\
\hline Spol & 0,09 & $0,14 * *$ & 0,06 \\
\hline Dob & $-0,25^{* *}$ & $-0,06$ & $-0,04$ \\
\hline Brižnost & $0,12 *$ & $0,23 * *$ & $0,24 * *$ \\
\hline Pravednost & 0,06 & 0,06 & $-0,04$ \\
\hline Lojalnost & $0,15^{*}$ & $0,15^{* *}$ & $0,12 *$ \\
\hline Autoritet & $0,15^{*}$ & $-0,01$ & $-0,04$ \\
\hline Čistoća & $-0,10$ & 0,09 & $0,13 *$ \\
\hline $\mathrm{R}$ & 0,38 & 0,43 & 0,35 \\
\hline $\mathrm{R}^{2}$ & 0,15 & 0,19 & 0,12 \\
\hline$\Delta \mathrm{R}^{2}$ & $0,08 * *$ & $0,15^{* *}$ & $0,11 * *$ \\
\hline$F(7,406)$ & $10,00 * *$ & $13,31 * *$ & $8,16^{* *}$ \\
\hline Spol & 0,07 & 0,09 & 0,04 \\
\hline Dob & $-0,25^{* *}$ & $-0,06$ & $-0,04$ \\
\hline Brižnost & 0,09 & $0,22 * *$ & $0,23 * *$ \\
\hline Pravednost & 0,04 & 0,11 & $-0,05$ \\
\hline Lojalnost & $0,17 * *$ & 0,10 & $0,18^{*}$ \\
\hline Autoritet & $0,17 * *$ & $-0,04$ & $-0,03$ \\
\hline Čistoća & $-0,07$ & 0,02 & $0,14^{*}$ \\
\hline Religioznost & $-0,03$ & $0,27 * *$ & 0,02 \\
\hline Ideologija & $-0,16^{* *}$ & $-0,04$ & $-0,11^{*}$ \\
\hline $\mathrm{R}$ & 0,42 & 0,49 & 0,37 \\
\hline $\mathrm{R}^{2}$ & 0,17 & 0,24 & 0,13 \\
\hline$\Delta \mathrm{R}^{2}$ & $0,03 * *$ & $0,05^{* *}$ & 0,01 \\
\hline $\mathrm{F}(9,404)$ & $9,42 * *$ & $14,19^{* *}$ & $6,92 * *$ \\
\hline
\end{tabular}

$* p<0,05 ; * *<0,01$

\section{RASPRAVA}

Cilj je provedenog istraživanja bio ispitati ulogu religioznosti, društvene ideologije i moralnih temelja koji uključuju brižnost, pravednost, lojalnost prema vla- 
stitoj skupini, poštovanje autoriteta te tjelesnu i duhovnu čistoću u objašnjenju triju specifičnih orijentacija prema sreći, onih prema ugodnom, smislenom i angažiranom životu. Dobiveni rezultati izdvojili su moralne temelje lojalnosti i podložnosti autoritetu, kao i liberalniju društvenu ideologiju te mlađu životnu dob kao statistički značajne prediktore orijentacije prema ugodnom životu. Uz to, moralni temelji brižnosti, lojalnosti i čistoće, kao i liberalnija društvena orijentacija, predviđali su veću usmjerenost prema angažiranom životu, pri čemu se brižnost, zajedno s religioznošću, pokazala i kao značajan prediktor orijentacije prema smislenom životu.

Ovakva je uloga religioznosti bila očekivana te su dobiveni rezultati potvrdili postavljenu hipotezu prema kojoj se očekivalo da će ova varijabla predviđati orijentaciju prema smislenom životu. Naime, spomenuta je hipoteza postavljena na temelju prethodnih istraživanja koja pokazuju kako vjera pojedincima nudi osjećaj svrhe i životnog smisla koje oni često doživljavaju prioritetnima u životu (Schlenker i sur., 2012). Graham i Haidt (2010) to povezuju s teorijom upravljanja strahom koja navodi da religija ima palijativnu funkciju, odnosno da religijska vjerovanja služe tome da ublažavaju tjeskobu zbog straha od smrti i besmisla. Također, vjera u boga koji kontrolira događanja pomaže ljudima u situacijama nad kojima nemaju osobnu kontrolu, a neki autori upućuju i na važnost religije kod izgradnje samokontrole i samoregulacije, što su karakteristike koje mogu rezultirati višom dobrobiti, slično kao i integracija pojedinaca u vjerske zajednice (Lim i Putnam, 2010; McCullough i Willoughby, 2009; Sheldon i Houser-Marko, 2001). Rezultati dobiveni provedenim istraživanjem pokazuju da je religioznost važna ne samo za doživljaj smislenosti u životu već i za formuliranje uvjerenja o važnosti tog temelja za ostvarivanje ispunjenog i zadovoljnog života.

Osim religioznosti, kao značajan prediktor ove orijentacije izdvojena je i brižnost, što se može dovesti u vezu s prirodom ovog moralnog temelja koji se odnosi na senzibilitet i empatiju prema drugima (Haidt i Kesebir, 2010). S obzirom na socijalnu usmjerenost koja leži u osnovi ovog temelja, može se pretpostaviti da je on pozitivno povezan sa subjektivnom dobrobiti pojedinca jer ljudi prepoznaju važnost društvenog angažmana i socijalnih veza općenito za ostvarivanje dugoročne sreće (Caunt, Franklin, Brodaty, i Brodaty, 2013; Delle Fave i sur., 2011; Delle Fave i sur., 2016), što onda rezultira i većom učestalosti doživljavanja sreće kod socijalno integriranih pojedinaca (Diener i Seligman, 2002; Lyubomirsky i sur., 2005), odnosno izraženijim negativnim afektom kod socijalno izoliranih ili usamljenih pojedinaca (Baumeister, Vohs, Aaker, i Garbinsky, 2013; Cacioppo i Patrick, 2008). Istraživanja pokazuju da su socijalne veze, osim za općenitu subjektivnu dobrobit, naročito važne za doživljaj smisla te da vrlo često procjene pojedinaca o smislenosti vlastitog života pokazuju određenu povezanost s percepcijom osobe da ima snažne veze s obitelji i prijateljima (Debats, 1999; Lambert i sur., 2010). Pritom je za doživljaj smislenosti posebno važan osjećaj da osoba doprinosi i pomaže, odnosno daje drugima, pri čemu je taj isti doživljaj negativno povezan sa suprotnim osjećajem, odnosno procjenom da osoba od drugih najčešće nešto uzima (Baumeister i 
sur., 2013). Naime, briga i provođenje vremena s ljudima koji pojedincima u životu znače pozitivno je povezana s osjećajem smisla, ali ne nužno i s hedonističkim doživljajem sreće, pri čemu osobe koje svoj život u većoj mjeri opisuju smislenim uz to i više vrednuju važnost bliskih međuljudskih odnosa koje u životu njeguju (Baumeister i sur., 2013). Rezultati našeg istraživanja u skladu su s ovim nalazima jer se moralni temelj brižnosti referira upravo na ono što pojedinac može napraviti za svoje bližnje, a ne naglašavanje važnosti povezivanja s drugim kako bi osoba ugodnije provela vrijeme ili se okoristila osobama koje je okružuju (Haidt i Joseph, 2004; Haidt i Kesebir, 2010). Dok prethodna istraživanja pokazuju kako je snažniji osjećaj smisla povezan s procjenom da osoba pokušava pomoći drugima kojima je pomoć potrebna (Baumeister i sur., 2013), naši rezultati upućuju na zaključak da osobe usmjerene na brigu o drugima ujedno i teže smislenom životu više od onih s manje izraženim moralnim temeljom brižnosti.

Vjerojatno se na sličan način može interpretirati i doprinos ovog temelja orijentaciji prema angažiranom životu. Naime, briga za ljude i želja da im se pomogne svakako može biti motivirajuća za uključivanje u različite društvene aktivnosti usmjerene na brigu o pojedincima, kao i vrednovanje takve vrste angažmana u svakodnevnom životu. Slično kao i moralni temelj brižnosti, i onaj lojalnosti grupi koji je također izdvojen kao statistički značajan prediktor orijentacije prema angažiranom životu također se može dovesti u vezu sa socijalnim angažmanom pojedinca te suradnjom s pojedincima unutar vlastite grupe (Haidt i Kesebir, 2010). Naime, može se spekulirati da ova dva temelja predstavljaju dvije strane moguće socijalne orijentacije prema drugim, s jedne strane pojedincima, a s druge skupinama pojedinaca, što može rezultirati većom angažiranošću u socijalnom okruženju koja, kao što je spomenuto, može voditi većoj subjektivnoj dobrobiti pojedinaca (Caunt i sur., 2013; Delle Fave i sur., 2016; Lyubomirsky i sur., 2005).

Nadalje, kao dodatni prediktor ove orijentacije izdvojen je i moralni temelj čistoće koji predstavlja jedan od složenijih "povezujućih" moralnih temelja koji se podjednako može povezati s tjelesnim, kao i duhovnim aspektima brige o tijelu (Haidt i Kesebir, 2010). Iako se na prvi pogled može pretpostaviti da ovaj moralni temelj ne bi trebao imati značajniji utjecaj na orijentacije prema sreći, osim možda one prema smislenom životu, rezultati regresijske analize pokazuju da je on povezan i s usmjerenošću prema smislenom, kao i angažiranom životu. Međutim, unatoč statistički značajnoj povezanosti s orijentacijom prema smislenom životu, nedostatak njegova doprinosa koji je utvrđen u regresiji vjerojatno se može povezati sa složenim međudjelovanjem ovog temelja s onim lojalnosti grupi, kao i religioznošću, $\mathrm{s}$ obzirom na to da je u drugom koraku regresijske analize lojalnost izdvojena kao značajan prediktor ove orijentacije, pri čemu je u trećem koraku, nakon uključenja religioznosti u analizu, izgubila značajnost. S druge strane, u oba koraka regresijske analize moralni je temelj čistoće izdvojen kao značajan prediktor orijentacije prema angažiranom životu, što se može dovesti s prethodnim istraživanjima koja pokazuju njegovu važnost za jedan oblik društveno angažiranog djelovanja, onaj 
usmjeren prema borbi za okoliš (Dickinson, McLeod, Bloomfield, i Allred, 2016; Feinberg i Willer, 2011). Naime, u tim su istraživanjima dva moralna temelja izdvojena kao prediktori pozitivnih ekoloških stavova i aktivističkog djelovanja, i to temelj brižnosti i suosjećanje koje se nalazi u njegovoj osnovi te upravo čistoća, što autori čak dovode u vezu s afektivnim potencijalom obaju ovih temelja, onome prema empatiji u slučaju brižnosti te gađenja u slučaju čistoće (Dickinson i sur., 2016; Graham i sur., 2011).

Manje je začudno što je kao prediktor usmjerenosti prema angažiranom životu izdvojena i liberalna društvena ideologija, što se vjerojatno može interpretirati činjenicom da konzervativnost kao socijalnu ideologiju karakterizira racionalizacija postojećih društvenih, ekonomskih i političkih institucija i poredaka. U tom smislu, konzervativnost je ideologija koja štiti i opravdava postojeći sustav te na taj način pojedincu služi kao zaštita od negativnih hedoničkih posljedica socijalnih i ekonomskih nejednakosti u društvu danas te ga, na palijativan način, čini zadovoljnijim životom (Jost i Hunyady, 2003; Jost i sur., 2008). Kolateralna posljedica tog stava je, kako pokazuju rezultati provedenog istraživanja, i činjenica da su konzervativni pojedinci manje skloni vrednovati angažman u društvu u kojem žive kao nešto što bi im život moglo obogatiti, odnosno povećati im subjektivnu dobrobit.

Osim što su više usmjereni prema angažiranom, liberalniji pojedinci su više usmjereni i prema ugodnom životu, što je u skladu s postavljenim hipotezama. Naime, u istraživanju smo očekivali da će liberalni pojedinci više vrednovati ugodan život u usporedbi s onima konzervativnog svjetonazora, koji su u pravilu skloniji odgađati gratifikaciju, naročito onu frivolnije vrste (Harrison i McKay, 2013), pri čemu takva veća usmjerenost prema ugodnom životu može rezultirati i povećanim pozitivnim afektom (Choma, Shove, Busseri, Sadava, i Hosker, 2009). Osim liberalnog društvenog svjetonazora, kao značajni prediktori ove orijentacije izdvojena su i dva "povezujuća" moralna temelja koja se tradicionalno češće povezuju s konzervativnim pogledom na društvo (Graham i Haidt, 2010) te stoga u ovom istraživanju nismo očekivali njihov doprinos. Iako iznenađujući, ovi se rezultati možda mogu dovesti u vezu s povezanosti "povezujućih" moralnih temelja, prije svega lojalnosti skupini i prihvaćanju hijerarhijskih odnosa i autoriteta unutar nje, sa socijalnom integracijom pojedinaca (Haidt i Kesebir, 2010) koja, kao što smo ranije naveli, može različito utjecati na različite aspekte doživljavanja sreće. Naime, iako je socijalna povezanost s drugima općenito značajna za subjektivnu dobrobit pojedinaca (Helliwell i Putnam, 2004), ranije spomenuti nalazi pokazuju kako međuljudske interakcije usmjerene prema davanju drugima povećavaju osjećaj smislenosti vlastitog života, dok su one usmjerene prema zabavnom provođenju vremena ili povećavanju vlastite koristi više povezane s hedonističkim doživljajem pojedinca (Baumeister i sur., 2013). Iako su dodatna istraživanja potrebna za detaljniju analizu socijalne usmjerenosti i primarnih doživljaja koje se nalaze u osnovi moralnih temelja brižnosti te pripadanju skupini i poštivanju autoriteta, moguće je spekulirati da se one međusobno razlikuju, $i$ to na način da su oni koje više vrednuju moralni 
temelj brižnosti više usmjereni na davanje, a oni koje motiviraju dva spomenuta "povezujuća" temelja usmjereniji na primanje, odnosno dijeljenje iskustava, što bi se onda moglo dovesti u vezu s različitim doprinosima ovih temelja orijentacijama prema smislenom i ugodnom životu. Nadalje, ovi bi se rezultati mogli dovesti u vezu i s nalazima koji upućuju na važnost kognitivnih činitelja u objašnjenju individualnih razlika u moralnom rezoniranju. Naime, dok su se Haidt i suradnici (Graham i sur., 2011; Haidt, 2001; Haidt i Kesebir, 2010) u razvoju teorije moralnih temelja usmjeravali prvenstveno na utjecaj kulturalnih i okolinskih činitelja, drugi su autori pokazali da razlike u kognitivnim sposobnostima i vještinama nezavisno predviđaju "povezujuće" moralne temelje, i to na način da refleksivnije i analitičnije osobe rjeđe vrednuju ovakve vrijednosti (Pennycook, Cheyne, Barr, Koehler i Fugelsang, 2014). S obzirom da se i orijentacija prema smislu također više vezuje uz refleksivnost te promišljanje sebe i svijeta koji pojedinca okružuje (Huta, 2015; Huta i Waterman, 2014; Steger, Shin, Shim i Fitch-Martin, 2013), moguće je spekulirati da bi se i važnost različitih moralnih temelja i vrijednosti općenito za načine konceptualizacije sreće također mogla vezati uz generalne obrasce prosuđivanja i kognitivne stilove, što treba ispitati unutar budućih istraživanja. Na kraju, treba istaknuti kako je, osim spomenutih moralnih temelja i liberalnog društvenog svjetonazora, i mlađa dob izdvojena kao prediktor orijentacije prema ugodnom životu, što je u skladu s prethodnim nalazima koji upućuju na važnost ugode i zabave za osobe mlađe životne dobi (Peterson i sur., 2005; San Martín, Perles i Canto, 2010).

Iako provedeno istraživanje odrednica orijentacija prema sreći proširuje prethodne nalaze u ovom području, prilikom interpretacije dobivenih rezultata treba istaknuti nekoliko nedostataka koji mogu ograničiti njihovu generalizaciju. Naime, provedeno je istraživanje bilo korelacijsko i utemeljeno na samoprocjenama sudionika te stoga ne nudi mogućnost zaključivanja o uzročno-posljedičnim vezama među varijablama (McDonald, 2008; Paulhus i Vazire, 2007). Također, uzorak sudionika nije bio do kraja izjednačen po spolu te je uključivao pretežno sudionike mlađe životne dobi. Moguće je pretpostaviti da je veća zastupljenost žena u našem uzorku doprinijela blago liberalnijoj ideologiji koju su u prosjeku naveli naši sudionici, s obzirom na to da tablica korelacija pokazuje nešto izraženiju liberalnu poziciju među sudionicama istraživanja, što je u skladu s prethodnim istraživanjima (Čorkalo, Kamenov i Tadinac-Babić, 2001). Nadalje, kao nedostatak istraživanja može se spomenuti snižena pouzdanost subskala Upitnika moralnih temelja, što je vezano uz činjenicu da se svaka od njih sastoji od četiri raznolike čestice, od kojih su dvije formulirane kao pitanja, a dvije kao tvrdnje zbog čega su ovakve vrijednosti pouzdanosti bile očekivane. Stoga smo u evaluaciji skala, osim Cronbachova $\alpha$ indeksa pouzdanosti, u obzir uzeli i broj te korelacije između pojedinačnih čestica (Briggs i Cheek, 1986; Clark i Watson, 1995; Cortina, 1993; Lance, Butts, i Michels, 2006; Robinson, Shaver i Wrightsman, 1991) kao i prethodna iskustva u korištenju ovog instrumenta koja pokazuju sniženu pouzdanost ove, kraće forme (Graham i sur., 2009). Međutim, u budućim se istraživanjima preporuča koristiti dužu verziju 
ovog upitnika te ispitivanje proširiti na šire društvene vrijednosti pojedinaca. Nadalje, u budućim se istraživanjima može detaljnije ispitati međuodnos socijalne integracije, moralnih temelja te uvjerenja o uzrocima sreće i same subjektivne dobrobiti, kao i važnost kognitivnih činitelja u konceptualizaciji sreće. Njihovi, kao i nalazi provedenog istraživanja mogu pomoći u razumijevanju odrednica načina na koji pojedinci prosuđuju o tome što čini sretan život, kao i njihove povezanosti sa subjektivnom dobrobiti pojedinaca.

\section{LITERATURA}

Baumeister, R. F., Bauer, I. M., Lloyd, S. A. (2010). Choice, free will, and religion. Psychology of Religion and Spirituality, 2(2), 67-82. doi: 10.1037/a0018455

Baumeister, R. F., Vohs, K. D., Aaker, J. L., Garbinsky, E. N. (2013). Some key differences between a happy life and a meaningful life. The Journal of Positive Psychology, 8(6), 505-516. doi: 10.1080/17439760.2013.830764

Bezinović, P., Marinović Bobinac, A., Marinović Jerolimov, D. (2005). Kratka ljestvica religioznosti: Validacija na uzorku adolescenata. Društvena Istraživanja, 14(1-2), 135153.

Braaten, A., Huta, V. (2018). A preliminary exploration of how worldviews relate to eudaimonic and hedonic orientations. International Journal of Existential Psychology and Psychotherapy, 7(2), 1-11.

Brdar, I., Anić, P. (2010). Životni ciljevi, orijentacije prema sreći i psihološke potrebe adolescenata: Koji je najbolji put do sreće. Psihologijske Teme, 19(1), 169-187.

Brdar, I., Kashdan, T. B. (2010). Character strengths and well-being in Croatia: An empirical investigation of structure and correlates. Journal of Research in Personality, 44(1), 151-154. doi: 10.1016/j.jrp.2009.12.001

Briggs, S. R., \& Cheek, J. M. (1986). The role of factor analysis in the development and evaluation of personality scales. Journal of Personality, 54(1), 106-148. doi:10.1111/j.1467-6494.1986.tb00391.x

Bubić, A., Erceg, N. (2018). Znamo li što nas čini sretnima? Važnost laičkih uvjerenja o uzrocima sreće i vrijednosti za doživljaj sreće. Primenjena Psihologija, 11(3), 345-364. doi: 10.19090/pp.2018.3.345-364

Cacioppo, J. T., Patrick, W. (2008). Loneliness: Human nature and the need for social connection. WW Norton \& Company.

Carney, D. R., Jost, J. T., Gosling, S. D., Potter, J. (2008). The secret lives of liberals and conservatives: Personality profiles, interaction styles, and the things they leave behind. Political Psychology, 29(6), 807-840. doi: 10.1111/j.1467-9221.2008.00668.x

Caunt, B. S., Franklin, J., Brodaty, N. E., Brodaty, H. (2013). Exploring the causes of subjective well-being: A content analysis of peoples' recipes for long-term happiness. Journal of Happiness Studies, 14(2), 475-499. doi: 10.1007/s10902-012-9339-1

Choma, B. L., Shove, C., Busseri, M. A., Sadava, S. W., Hosker, A. (2009). Assessing the role of body image coping strategies as mediators or moderators of the links between self-objectification, body shame, and well-being. Sex Roles, 61(9-10), 699-713fd. doi: $10.1007 / \mathrm{s} 11199-009-9666-9$ 
Clark, L. A., \& Watson, D. (1995). Constructing validity: Basic issues in objective scale development. Psychological Assessment, 7(3), 309-319. doi:10.1037/1040-3590.7.3.309

Cortina, J. M. (1993). What is coefficient alpha? An examination of theory and applications. Journal of Applied Psychology, 78(1), 98-104. doi: 10.1037/0021-9010.78.1.98

Csikszentmihalyi, M. (2014). Toward a psychology of optimal experience. U M. Csikszentmihalyi (Ur.), Flow and the Foundations of Positive Psychology (str. 209-226). Dordrecht: Springer.

Čorkalo, D., Kamenov, Ž., \& Tadinac-Babić, M. (2001). Autoritarnost, stav prema stanju demokracije i percepcija razvojnih ciljeva Hrvatske. Društvena istraživanja, 10(6 (56)), 1159-1177. doi: 316.64:321.7

Debats, D. L. (1999). Sources of meaning: An investigation of significant commitments in life. Journal of Humanistic Psychology, 39(4), 30-57. doi: 10.1177/0022167899394003

Delle Fave, A., Brdar, I., Freire, T., Vella-Brodrick, D., Wissing, M. P. (2011). The eudaimonic and hedonic components of happiness: Qualitative and quantitative findings. Social Indicators Research, 100(2), 185-207. doi: 10.1007/s11205-010-9632-5

Delle Fave, A., Brdar, I., Wissing, M. P., Araujo, U., Castro Solano, A., Freire, T., ... others. (2016). Lay definitions of happiness across nations: The primacy of inner harmony and relational connectedness. Frontiers in Psychology, 7, 30. doi: 10.3389/fpsyg.2016.00030

Dickinson, J. L., McLeod, P., Bloomfield, R., Allred, S. (2016). Which moral foundations predict willingness to make lifestyle changes to avert climate change in the USA? PloS One, 11(10), e0163852. doi: 10.1371/journal.pone.0163852

Diener, E., Seligman, M. E. (2002). Very happy people. Psychological Science, 13(1), 8184. doi: 10.1111/1467-9280.00415

Dweck, C. S., Chiu, C., Hong, Y. (1995). Implicit theories and their role in judgments and reactions: A word from two perspectives. Psychological Inquiry, 6(4), 267-285.

Emmons, R. A., McCullough, M. E. (2003). Counting blessings versus burdens: An experimental investigation of gratitude and subjective well-being in daily life. Journal of Personality and Social Psychology, 84(2), 377-389. doi: 10.1037/0022-3514.84.2.377

Feather, N. T. (1984). Protestant ethic, conservatism, and values. Journal of Personality and Social Psychology, 46(5), 1132-1141. doi: 10.1037/0022-3514.46.5.1132

Feinberg, M., Willer, R. (2011). Apocalypse soon? Dire messages reduce belief in global warming by contradicting just-world beliefs. Psychological Science, 22(1), 34-38. doi: $10.1177 / 0956797610391911$

Fujita, F., Diener, E. (2005). Life satisfaction set point: Stability and change. Journal of Personality and Social Psychology, 88(1), 158-164. doi: 10.1037/0022-3514.88.1.158

Furnham, A., Cheng, H. (2000). Lay theories of happiness. Journal of Happiness Studies, $1(2), 227-246$.

Gilligan, C. (1983). In a Different Voice: Psychological Theory and Women's Development. Boston, MA: Harvard University Press.

Graham, J., Haidt, J. (2010). Beyond beliefs: Religions bind individuals into moral communities. Personality and Social Psychology Review, 14(1), 140-150. doi: $10.1177 / 1088868309353415$ 
Graham, J., Haidt, J., Nosek, B. A. (2009). Liberals and conservatives rely on different sets of moral foundations. Journal of Personality and Social Psychology, 96(5), 1029-1046. doi: $10.1037 / \mathrm{a} 0015141$

Graham, J., Nosek, B. A., Haidt, J., Iyer, R., Koleva, S., Ditto, P. H. (2011). Mapping the moral domain. Journal of Personality and Social Psychology, 101(2), 366-385. doi: $10.1037 / \mathrm{a} 0021847$

Haidt, J. (2001). The emotional dog and its rational tail: A social intuitionist approach to moral judgment. Psychological Review, 108(4), 814-834. doi: 10.1037/0033-295X.108.4.814

Haidt, J., Graham, J. (2007). When morality opposes justice: Conservatives have moral intuitions that liberals may not recognize. Social Justice Research, 20(1), 98-116. doi: 10.1007/s11211-007-0034-z

Haidt, J., Graham, J., Joseph, C. (2009). Above and below left-right: Ideological narratives and moral foundations. Psychological Inquiry, 20(2-3), 110-119. doi: $10.1080 / 10478400903028573$

Haidt, J., Joseph, C. (2004). Intuitive ethics: How innately prepared intuitions generate culturally variable virtues. Daedalus, 133(4), 55-66. doi: 10.1162/0011526042365555

Haidt, J., Kesebir, S. (2010). Morality. U J. Haidt, S. Kesebir, S. T. Fiske, D. Gilbert, \& G. Lindzey (Ur.), Handbook of Social Psychology (str. 797-832). New York, NY: Wiley.

Harrison, J. M. D., McKay, R. T. (2013). Do religious and moral concepts influence the ability to delay gratification? A priming study. Journal of Articles in Support of the Null Hypothesis, 10(1), 25-40.

Helliwell, J. F., Putnam, R. D. (2004). The social context of well-being. Philosophical Transactions of the Royal Society of London. Series B: Biological Sciences, 359(1449), 1435-1446. doi: 10.1098/rstb.2004.1522

Huta, V. (2015). The complementary roles of eudaimonia and hedonia and how they can be pursued in practice. U S. Joseph (Ur.), Positive psychology in practice: Promoting human flourishing in work, health, education, and everyday life (str. 159-182). Wiley.

Huta, V., Waterman, A. S. (2014). Eudaimonia and its distinction from hedonia: Developing a classification and terminology for understanding conceptual and operational definitions. Journal of Happiness Studies, 15(6), 1425-1456. doi: 10.1007/s10902-013-9485-0

Jost, J. T., Hunyady, O. (2003). The psychology of system justification and the palliative function of ideology. European Review of Social Psychology, 13(1), 111-153. doi: 10.1080/10463280240000046

Jost, J. T., Nosek, B. A., Gosling, S. D. (2008). Ideology: Its resurgence in social, personality, and political psychology. Perspectives on Psychological Science, 3(2), 126-136. doi: 10.1111/j.1745-6916.2008.00070.x

Keltner, D., Bonanno, G. A. (1997). A study of laughter and dissociation: distinct correlates of laughter and smiling during bereavement. Journal of Personality and Social Psychology, 73(4), 687-702. doi: 10.1037/0022-3514.73.4.687

Kohlberg, L. (1969). Stages in the development of moral thought and action. New York, NY: Holt, Rinehart \& Winston.

Lambert, N. M., Stillman, T. F., Baumeister, R. F., Fincham, F. D., Hicks, J. A., Graham, S. M. (2010). Family begets meaning: The unique contribution of family relationships to purpose in life. Journal of Positive Psychology, 5, 367-37. 
Lance, C. E., Butts, M. M., \& Michels, L. C. (2006). The sources of four commonly reported cutoff criteria: What did they really say? Organizational Research Methods, 9(2), 202220. doi:10.1177/1094428105284919

Lim, C., Putnam, R. D. (2010). Religion, social networks, and life satisfaction. American Sociological Review, 75(6), 914-933. doi: 10.1177/0003122410386686

Lu, L., Gilmour, R. (2004). Culture and conceptions of happiness: Individual oriented and social oriented SWB. Journal of Happiness Studies, 5(3), 269-291. doi: 10.1007/ s10902-004-8789-5

Lu, L., Gilmour, R., Kao, S.-F., Weng, T.-H., Hu, C.-H., Chern, J.-G., ... Shih, J.-B. (2001). Two ways to achieve happiness: When the East meets the West. Personality and Individual Differences, 30(7), 1161-1174. doi: 10.1016/S0191-8869(00)00100-8

Lu, L., Shih, J. B. (1997). Sources of happiness: A qualitative approach. The Journal of Social Psychology, 137(2), 181-187. doi: 10.1080/00224549709595429

Lyubomirsky, S., Sheldon, K. M., Schkade, D. (2005). Pursuing happiness: The architecture of sustainable change. Review of General Psychology, 9(2), 111-131. doi: 10.1037/1089-2680.9.2.111

McCullough, M. E., Willoughby, B. L. (2009). Religion, self-regulation, and self-control: Associations, explanations, and implications. Psychological Bulletin, 135(1), 69-93. doi: $10.1037 / \mathrm{a} 0014213$

McDonald, J. D. (2008). Measuring personality constructs: The advantages and disadvantages of self-reports, informant reports and behavioural assessments. Enquire, 1(1), 1-18.

Myers, D. G. (2000). The funds, friends, and faith of happy people. American Psychologist, 55(1), 56-67. doi: 10.1037/0003-066X.55.1.56

Napier, J. L., Jost, J. T. (2008). Why are conservatives happier than liberals? Psychological Science, 19(6), 565-572. doi: 10.1111/j.1467-9280.2008.02124.x

Onraet, E., Van Hiel, A., Dhont, K. (2013). The relationship between right-wing ideological attitudes and psychological well-being. Personality and Social Psychology Bulletin, 39(4), 509-522. doi: 10.1177/0146167213478199

Paulhus, D. L., Vazire, S. (2007). The self-report method. U R. W. Robins, R. C. Fraley, R. F. Krueger (Ur.), Handbook of research methods in personality psychology (str. 224-239). New York: Guilford Press.

Pennycook, G., Cheyne, J. A., Barr, N., Koehler, D. J., Fugelsang, J. A. (2014). The role of analytic thinking in moral judgements and values. Thinking \& Reasoning, 20(2), 188-214. doi: 10.1080/13546783.2013.865000

Peterson, C., Park, N., Seligman, M. E. P. (2005). Orientations to happiness and life satisfaction: The full life versus the empty life. Journal of Happiness Studies, 6(1), 25-41. doi: 10.1007/s10902-004-1278-z

Peterson, C., Ruch, W., Beermann, U., Park, N., Seligman, M. E. P. (2007). Strengths of character, orientations to happiness, and life satisfaction. The Journal of Positive Psychology, 2(3), 149-156. doi: 10.1080/17439760701228938

Pflug, J. (2009). Folk theories of happiness: A cross-cultural comparison of conceptions of happiness in Germany and South Africa. Social Indicators Research, 92(3), 551-563. doi: $10.1007 / \mathrm{s} 11205-008-9306-8$ 
Pollock, N. C., Noser, A. E., Holden, C. J., Zeigler-Hill, V. (2015). Do orientations to happiness mediate the associations between personality traits and subjective well-being? Journal of Happiness Studies, 1-17. doi: 10.1007/s10902-015-9617-9

Robinson, J. P., Shaver, P. R., \& Wrightsman, L. S. (1991). Criteria for scale selection and evaluation. In J. P. Robinson, P. R. Shaver, \& L. S. Wrightsman (Eds.), Measures of personality and social psychological attitudes (Vol. 1, pp. 1-16). San Diego, CA: Academic Press.

San Martín, J., Perles, F., Canto, J. M. (2010). Life satisfaction and perception of happiness among university students. The Spanish Journal of Psychology, 13(2), 617-628. doi: $10.1017 / \mathrm{S} 1138741600002298$

Schlenker, B. R., Chambers, J. R., Le, B. M. (2012). Conservatives are happier than liberals, but why? Political ideology, personality, and life satisfaction. Journal of Research in Personality, 46(2), 127-146. doi: 10.1016/j.jrp.2011.12.009

Schwartz, S. H. (1992). Universals in the content and structure of values: Theoretical advances and empirical tests in 20 countries. Advances in Experimental Social Psychology, 25(1), 1-65. doi: 10.1016/S0065-2601(08)60281-6

Schwartz, S. H. (2003). A proposal for measuring value orientations across nations. U Questionnaire Package of the European Social Survey (str. 259-290). Dostupno na http:// www.europeansocialsurvey.org/docs/methodology/core_ess_questionnaire/ESS_core questionnaire_human_values.pdf

Seybold, K. S., Hill, P. C. (2001). The role of religion and spirituality in mental and physical health. Current Directions in Psychological Science, 10(1), 21-24. doi: 10.1111/14678721.00106

Sheldon, K. M., Houser-Marko, L. (2001). Self-concordance, goal attainment, and the pursuit of happiness: Can there be an upward spiral? Journal of Personality and Social Psychology, 80(1), 152-165. doi: 10.1037/0022-3514.80.1.152

Steger, M. F., Shin, J. Y., Shim, Y., Fitch-Martin, A. (2013). Is meaning in life a flagship indicator of well-being? U A. S. Waterman (Ur.), The best within us: Positive psychology perspectives on eudaimonia (str. 159-182). Washington, DC: American Psychological Association.

Taylor, P., Funk, C., Craighill, P. (2006). Are we happy yet. PewResearchCenter.

Vella-Brodrick, D. A., Park, N., Peterson, C. (2009). Three ways to be happy: Pleasure, engagement, and meaning-Findings from Australian and US samples. Social Indicators Research, 90(2), 165-179. doi: 10.1007/s11205-008-9251-6

Verhulst, B., Eaves, L. J., Hatemi, P. K. (2012). Correlation not causation: The relationship between personality traits and political ideologies. American Journal of Political Science, 56(1), 34-51. doi: 10.1111/j.1540-5907.2011.00568.x 


\title{
CONTRIBUTIONS OF MORAL FOUNDATIONS, RELIGIOUSNESS AND IDEOLOGY IN EXPLAINING ORIENTATIONS TO HAPPINESS
}

\begin{abstract}
Investigating the way individuals conceptualize happiness, i.e., their beliefs about what constitutes a happy life, represents an important aspect of understanding subjective well-being because such beliefs don't just reflect their judgments but also influence their experienced happiness. Previous studies that have focused on this phenomenon have identified three main orientations to happiness, namely those aimed at living a life of pleasure, meaning or engagement. Given that the factors that contribute to the development of such orientations are still not well known, within the present study conducted on a sample of 415 participants we aimed at investigating the role of religiousness, ideology and moral foundations that include harm/care, fairness/reciprocity, ingroup/ loyalty, authority/respect, and purity/sanctity in developing the mentioned orientations to happiness. The obtained results identified foundations of ingroup/loyalty and authority/respect, as well as liberal ideology and younger age as statistically significant predictors of orientation towards a life of pleasure. Moral foundations of harm/care, ingroup/loyalty and purity/sanctity, together with liberal ideology predicted orientation towards engagement, whereas harm/care and religiousness predicted orientation towards meaning. The obtained results indicate that individuals' fundamental moral, religious and social beliefs and values contribute to their beliefs regarding ways of obtaining happiness, and indicate a need for future investigations into the relationships among values, orientations to happiness and well-being.
\end{abstract}

Key words: ideology, moral foundations, orientations to happiness, religiousness, subjective well-being

Primljeno:18. 06. 2019. 
